\title{
Pengaruh Pelatihan Pemberian MP ASI Kepada Ibu dengan Anak Baduta Di Kecamatan Sukmajaya Kota Depok Terhadap Pengetahuan dan Perilaku Pemberian MP ASI
}

\author{
Firlia Ayu Arini ${ }^{1}$ Nur Intania Sofianita ${ }^{2}$ Ibnu Malkan Bahrul Ilmi ${ }^{3}$ \\ ${ }^{1,2,3}$ Program Studi S1 Ilmu Gizi Fikes UPN “Veteran” Jakarta
}

\begin{abstract}
Abstrak
Prevalensi gizi kurang pada balita di Indonesia menurut RISKESDAS tahun 2013 adalah 19,6\% dan prevalensi stunting atau balita pendek sebesar 37,2\% . Praktik pemberian makanan pada bayi dan anak terutama di usia $0-23$ bulan harus dilakukan secara benar dan tepat. Kesalahan pemberian makanan di periode tersebut dapat mengakibatkan masalah gizi kurang dan balita pendek. Masalah gizi pada bayi dan anak disebabkan karena pemberian ASI dan Makanan Pendamping ASI (MP-ASI) yang tidak tepat secara jumlah dan kualitasnya. Tujuan dari penelitian ini adalah menganalisis pengaruh pelatihan pemberian MP-ASI terhadap pengetahuan dan perilaku ibu yang memiliki anak di bawah dua tahun dalam pemberian MP-ASI yang nantinya akan berdampak pada status gizi anak. Penelitian ini menggunakan desain studi kuasi eksperimental menggunakan kelompok kontrol dengan pengambilan data menggunakan kuesioner dan wawancara mengenai pengetahuan dan perilaku ibu dalam pemberian MP-ASI. Penelitian ini dilaksanakan pada bulan November 2016. Hasil penelitian menunjukkan perbedaan signifikan antara skor pengetahuan dan perilaku pemberian MPASI pada sebelum dan sesudah penyuluhan pada kelompok perlakuan dan kelompok kontrol (p: $<0.05)$. Terdapat perbedaan skor pengetahuan yang signifikan setelah pemberian penyuluhan dan pelatihan MP-ASI antara kelompok perlakuan dan kelompok kontrol (p:0.011) namun tidak terdapat perbedaan skor perilaku antara kelompok perlakuan dan kelompok kontrol baik pada sebelum maupun sesudah perlakuan. Peningkatan skor pengetahuan lebih baik pada kelompok yang diberikan penyuluhan dengan Modul MP-ASI dan Pelatihan pembuatan MP-ASI.
\end{abstract}

Kata kunci: Pengetahuan dan Perilaku, MP-ASI

\section{Effect of Training Complementary Feeding to Mother With Children under 2 years age Of Knowledge And Behavior Giving complementary feeding in Sukmajaya Depok City}

\begin{abstract}
Prevalence of wasting among children under five based on Basic Health Research in 2013 was $19,6 \%$ and stunting prevalence was 37,2\%. Feeding practice particularly for children aged 6 to 23 months should be given in the right way. Failure in giving complementary feeding for children might cause malnutrition and stunted. Problems in giving complementary feeding for children that might cause malnutrition there were lack of quality and quantity. The purpose of this study was to analyze the impact of complementary feeding practice workshop for mothers with children under two years old towards mothers knowledge and practice in giving complementary feeding that would affect children nutritional status. Design of this study was Quasi - experimental design with control group, data were collected by structured questionnaire to measure knowledge and practice before and after complementary feeding workshop. Study was started in November 2016. Result of the study showed that there was significant difference in knowledge and practice score, before and after intervention, both in intervention and control group (p: < 0.05). There was significant difference in knowledge score between intervention and control group after intervention ( $\mathrm{p}: 0.011$ ) but there was no significant difference in practice score, before and after intervention, between intervention and control group. Score of knowledge was proven better in intervention group that had been educated by module and complementary workshop.
\end{abstract}

Keywords: Mothers' Knowledge and Practice, Complementary Feeding

Korespondensi: Firlia, Program Studi S1 Ilmu Gizi Fikes UPN “Veteran” Jakarta, Jl. RS. Fatmawati, Pondok Labu Jakarta 12450, Mobile 081310753227,Email: firlianuryanto@ hotmail.com

Arini dkk, Pengaruh Pelatihan Pemberian MP ASI Kepada Ibu dengan Anak Baduta 


\section{Pendahuluan}

Makanan pendamping ASI (MP-ASI) merupakan makanan atau minuman tambahan yang mengandung zat gizi dan diberikan mulai usia 6 -24 bulan untuk memenuhi kebutuhan gizi selain dari ASI. Setelah bayi berusia 6 bulan, kebutuhan zat gizi makin bertambah seiring dengan pertumbuhan dan perkembangan bayi, sementara produksi ASI mulai menurun, karena itu bayi membutuhkan makanan tambahan sebagai pendamping ASI. Pemberian makanan tambahan yang tidak tepat kualitas dan kuantitasnya dapat menyebabkan gizi kurang yang berdampak pada gangguan pertumbuhan dan perkembangan apabila tidak segera diatasi (Mutalib, 2014).

Menurut laporan RISKESDAS 2013 balita gizi kurang di Indonesia tercatat sebesar 19,6\% dan masalah balita pendek yaitu stunting sebesar 37,2\%. Besaran prevalensi di Jawa Barat untuk gizi kurang di wilayah Jawa Barat masih di atas $15 \%$ dan angka stunting di atas $32 \%$. Penelitian yang dilakukan oleh Verawaty pada tahun 2010 di Desa Madandan Kecamatan Rantetayo Kabupaten Tana Toraja terdapat 19 anak $(54,3 \%)$ yang mendapatkan MP - ASI kurang dari 6 bulan sedangkan status gizi bayi yang dihitung dengan Z-Score menggunakan indeks BB/U, sebanyak $(17,1 \%)$ berstatus gizi kurang. Pada penelitian Al Fajr tahun 2016 di Kecamatan Sukmajaya Depok menunjukkan ibu yang memberikan MP-ASI sebelum usia 6 bulan sebesar $73 \%$ dengan jumlah balita usia 6 -24 bulan yang gizi kurang sebanyak $43 \%$.

WHO merekomendasikan untuk memberikan ASI secara eksklusif sampai bayi berusia 6 bulan dan memberikan MP-ASI sejak bayi berusia 6-24 bulan diteruskan dengan pemberian ASI sampai dengan usia 2 tahun atau lebih. Standar ini direkomnedasikan karena terbukti dapat menurunkan angka kematian anak dan meningkatkan kualitas hidup ibu sesuai dengan Millenium Development Goals keempat dan kelima. Risiko kematian balita yang diberikan ASI dan MP-ASI dengan baik dapat menurun sebsar 13\%. Pemberian MPASI yang tepat mulai usia enam bulan akan mengurangi risiko malnutrisi (Retno, 2013).

Berdasarkan hasil Susenas 2002 (datanya terlalu lama) terdapat banyak ibu yang memberi MP-ASI terlalu dini yaitu $23 \%$ pada usia $2-3$ bulan seperti bubur, nasi dan pisang, sedangkan $69 \%$ memberikan MP-ASI pada usia 4 - 5 bulan. Sebuah penelitian oleh Irawati tahun 2007 di Pusat Pelatihan dan pengembangan Gizi dan Makanan Departemen Kesehatan menunjukkan hasil bahwa lebih dari $50 \%$ bayi di Indonesia mendapat MP-ASI pada usia kurang dari 1 bulan. Menurut Susanty (2012) pemberian MP-ASI terlalu dini dapat menimbulkan gangguan pencernaan seperti diare, sebaliknya jika diberikan terlambat maka bayi tidak terpenuhi gizinya dan akan mengalami 
kesulitan belajar mengunyah serta tidak menyukai makanan padat (Mutalib, 2014).

Usia penyapihan 6-24 bulan merupakan usia yang sangat rawan karena pada usia ini merupakan masa peralihan dari ASI ke pengganti ASI atau ke makanan sapihan. Pemberian MP-ASI yang tidak tepat dalam jumlah yang cukup baik dari segi kuantitas maupun kualitas. akan mengakibatkan gangguan pertumbuhan dan kurang gizi. Oleh karena itu, untuk mengatasi masalah kurang gizi maka diperlukan perbaikan kuantitas dan kualitas MP-ASI. Untuk memperoleh MP-ASI yang baik secara kuantitas dan kualitas maka diperlukan peranan petugas kesehatan untuk memberikan informasi tentang praktek pemberian makanan yang baik untuk anak di bawah usia 2 tahun kepada ibu, pengasuh, dan keluarga. Hasil penelitian Aminah (2008) di Bogor menunjukkan ada perbedaan yang bermakna terhadap perubahan tumbuh kembang anak setelah mendapatkan penyuluhan dan simulasi MP-ASI selama 2 bulan (Chandradewi, 2012).

Sebuah penelitian oleh Bassichhetto dan Rea tahun 2008 mengevaluasi mengenai efektivitas pelatihan Pemberian Makanan Bayi dan Anak terhadap perubahan pengetahuan, sikap dan praktik tenaga kesehatan termasuk dokter dan ahli gizi. Hasilnya menunjukkan adanya peningkatan pengetahuan yang signifikan setelah pelatihan PMBA tersebut (Retno, 2013). Pada penelitian Mardiah (2002) berupa intervensi pemberian MP-ASI pada anak usia 6-24 bulan disertai dengan pendidikan kepada ibu berupa penyuluhan yang dilakukan selama 2 minggu menunjukkan perubahan status gizi yaitu peningkatan berat badan yang bermakna cukup baik sebesar 0,39 $\mathrm{kg}$ pada anak usia 611 bulan dan kenaikkan 0,49 $\mathrm{kg}$ pada kelompok anak usia 12-24 bulan. Penyuluhan gizi mempunyai pengaruh terhadap pola pikir dan tingkat kepedulian ibu untuk memberikan asupan makanan yang baik pada anaknya (Chandradewi, 2012).

Dari Uraian di atas dapat disimpulkan bahwa pemberian MP-ASI yang tidak cukup gizi secara kualitas dan kuantitas berdampak terhadap malnutrisi yaitu gizi kurang dan terjadinya stunting terutama pada anak di bawah usia 2 tahun. Bila tidak tertangani secara dini maka anak yang mengalami malnutrisi tersebut menjadi sumber daya manusia yang produktivitasnya rendah dan berisiko mengalami penyakit tidak menular. Peran petugas kesehatan dalam memberikan penyuluhan MP-ASI terbukti dapat meningkatkan pola pikir dan tingkat kepedulian ibu untuk memberikan asupan makanan yang baik,namun perlu ditambahkan praktik cara pembuatan MP-ASI supaya perilaku pemberian MP-ASI menjadi tepat secara jumlah dan jenisnya. Di Kecamatan Sukmajaya jumlah ibu yang memberikan MPASI secara dini sebanyak $73 \%$ dengan kejadian gizi kurang sebesar 43\%. Hasil penelitian Al Fajr menunjukkan terdapat 
hubungan antara perilaku ibu dalam pemberian MP-ASI dengan status gizi bayi usia 6-23 bulan $(p=0,004)$. Oleh karena itu peneliti akan menganalisis pengaruh pelatihan pemberian MP-ASI kepada Ibu dengan Baduta terhadap pengetahuan dan perilaku pemberian MP-ASI.

Di latar belakang tidak dijelaskan perbedaan metode yang digunakan dibandingkan penelitian terdahulu. Value yg berbeda apa dari pelatihan yg akan diberikan?shg terkesan mengulang penelitian yang sama

\section{Metode}

Penelitian ini dilaksanakan selama 2 bulan mulai dari bulan September 2016 sampai Oktober 2016 dijustifikasi kenapa peatihannya diberikan dalam kurun waktu tersebut?. Pelatihan dilakukan di Posyandu dan Puskesmas UPT Kecamatan Sukmajaya Depok, serta Laboratorium Kuliner UPNVJ. Bahan Pelatihan ini menggunakan Modul dan paket bahan pembuatan MP-ASI yang dipersiapkan oleh peneliti, Untuk peralatan memasak menggunakan lab UPNVJ dan peralatan memasak yang tersedia di Posyandu dan Puskesmas. Pada penelitian ini digunakan desain penelitian yaitu Quasi experimental pre and post test with control group" dengan intervensi pelatihan MP-ASI menggunakan MODUL MP-ASI. Rancangan ini terdapat kelompok kontrol (pembanding) memungkinkan peneliti melihat perubahanperubahan yang telah terjadi setelah adanya intervensi/program (Hasan, 2004).

Penelitian dilakukan untuk mengetahui perbedaan pengetahuan dan perilaku sebelum dan sesudah dilakukan Pelatihan MP-ASI kepada ibu dengan anak Baduta di Kecamatan Sukmajaya Kota Depok. Penelitian ini juga bertujuan untuk membandingkan pengetahuan dan perilaku pemberian MP-ASI pada kelompok kontrol yaitu Ibu yang tidak mendapatkan Pelatihan MP-ASI. Dengan demikian teridentifikasi adanya pengaruh Pelatihan MP-ASI terhadap pengetahuan dan perilaku pemberian MP-ASI. Hal ini sesuai dengan pendapat Sugiyono (2009) bahwa pada penelitian Quasi experimental dapat digunakan untuk membuktikan pengaruh suatu intervensi/perlakuan pada subyek dan mengukur hasil (efek) intervensi tersebut. Desain penelitian pre and post test with control group dapat dilihat pada skema berikut

Metode kuasi eksperimental nya dijelaskan lebih rinci. Dijelaskan step-step pelatihan yang diberikan kepada ibu. Modul MP ASI nya berisi materi apa saja. Diberikan dalam rentang waktu berapa lama setiap materi. Jumlah dan cara pemilihan sampel untuk kelompok intervensi dan kelompok kontrol belum begitu jelas di bagian metode ini. 
Skema 1. Desain Penelitian pre and post test with control group

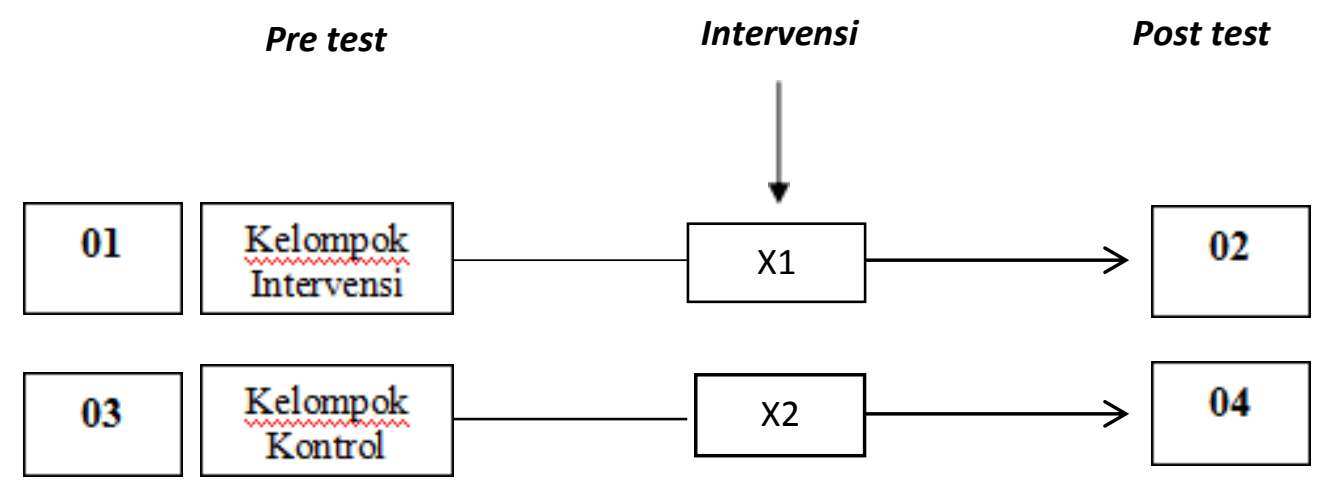

\section{Keterangan:}

X1 : Intervensi Kelompok Penyuluhan dan Pelatihan MP-ASI

X2: Penyuluhan MP-ASI tanpa Pelatihan

01: Pengetahuan dan Perilaku Ibu dalam Pemberian MP-ASI sebelum Pelatihan

02: Pengetahuan dan Perilak Ibu dalam Pemberian MP-ASI sesudah Pelatihan

03: Pengetahuan dan Perilaku Ibu dalam Pemberian MP-ASI pada kelompok kontrol

\section{Hasil Penelitian}

Responden dalam penelitian ini berjumlah 42 ibu dengan anak baduta yang terdiri atas 23 ibu pada kelompok intervensi dan 19 ibu pada kelompok kontrol. Jenis kelamin anak sebagian besar adalah perempuan $(57,1 \%)$. Rata-rata umur ibu adalah $30.05 \pm 6.81$ dan umur anak rata-
04: Pengetahuan dan Perilaku Ibu dalam Pemberian MP-ASI pada kelompok kontrol Teknik pengambilan sampel dalam penelitian ini menggunakan purposive sampling. PErhitungan sampel dengan rumus uji estimasi rata-rata mendapatkn hasil sampel untuk diuji beda sebelum dan sesudah perlakuan sebanyak 22 untuk kelompok intervensi dan 22 untuk kelompok kontrol.

ratanya 13.14 bulan \pm 4.98. Status gizi berdasarkan $\mathrm{BB} / \mathrm{U}$ anak pada seluruh responden menunjukkan rata-rata $-0,36 \pm$ 1.203 dengan nilai minimum -3.22 ( gizi kurang ) dan nilai maksimum 2.26 (gizi lebih). Distribusi Karakteristik Ibu dan Anak selengkapnya terdapat pada Tabel 1 
Tabel 5.1. Deskripsi Karakteristik Responden

\begin{tabular}{|c|c|c|c|c|}
\hline \multirow{2}{*}{ Karakteristik Responden } & \multicolumn{2}{|c|}{ Kelompok Perlakuan(n = 23) } & \multicolumn{2}{|c|}{ Kelompok kontrol $(n=19)$} \\
\hline & $\mathbf{N}$ & $\%$ & $\mathbf{n}$ & $\%$ \\
\hline \multicolumn{5}{|l|}{ Pendidikan terakhir } \\
\hline - Tamat SD & 0 & 0 & 5 & 26.3 \\
\hline - Tamat SLTP & 3 & 13 & 5 & 26.3 \\
\hline - Tamat SLTA & 18 & 78.4 & 9 & 47.4 \\
\hline -Pendidikan Tinggi & 2 & 8.6 & 0 & 0 \\
\hline \multicolumn{5}{|l|}{ Pendapatan } \\
\hline - < Rp. 1juta & 1 & 4.3 & 5 & 26.3 \\
\hline$-1-5$ juta & 20 & 87 & 13 & 68.4 \\
\hline - > 5 Juta & 2 & 8.7 & 1 & 5.3 \\
\hline \multicolumn{5}{|l|}{ Pekerjaan : } \\
\hline Tidak Bekerja & 21 & 91.3 & 18 & 94.7 \\
\hline Bekerja & 2 & 8.7 & 1 & 5.3 \\
\hline
\end{tabular}

Sebagian besar responden memiliki pendidikan terakhir tamat SLTA yaitu $78.4 \%$ pada kelompok perlakuan dan $47.4 \%$ pada kelompok kontrol. Pendapatan keluarga per bulan pada responden yang paling banyak adalah berkisar antara 1 sampai 5 juta rupiah yaitu $87 \%$ pada kelompok perlakuan dan $68,4 \%$ pada kelompok control. Hampir semua responden tidak bekerja baik pada kelompok perlakuan $(91.3 \%)$ maupun pada kelompok control (94.7\%). Menurut Ezzat (2007) faktor yang berhubungan terhadap pemberian MP-ASI, sumber informasi terkait MPASI salah satunya adalah tingkat pendidikan ibu. Sejalan dengan Ezzat, penelitian Liaqat pada 2006 juga membuktikan bahwa pendidikan ibu memiliki hubungan positif terhadap status gizi anak yang diberikan MP-ASI dan pengenalan MP-ASI pada usia anak di atas 6 bulan.

Tabel 5.2 Perubahan Parameter Pengetahuan dan Perilaku Ibu Sebelum dan Sesudah Pelatihan MPASI Pada Kelompok Perlakuan dan Kontrol

\begin{tabular}{|c|c|c|c|c|c|c|c|}
\hline \multirow[t]{2}{*}{ Variabel } & \multicolumn{3}{|c|}{ Kelompok Perlakuan } & \multicolumn{3}{|c|}{ Kelompok Kontrol } & \multirow[t]{2}{*}{$\mathrm{P}$} \\
\hline & Min & Maks & Rerata \pm SD & Min & Maks & Rerata \pm SD & \\
\hline $\begin{array}{l}\text { Pengetahuan } \\
\text { - Sebelum } \\
\text { - Setelah } \\
\text { - } \Delta \text { skor pengetahuan } \\
P\end{array}$ & $\begin{array}{l}10 \\
40 \\
0\end{array}$ & $\begin{array}{l}100 \\
100 \\
40\end{array}$ & $\begin{array}{l}78,7 \pm 4.28 \\
90 \pm 2.74 \\
11.3 \pm 12.9 \\
\\
\mathbf{p = 0 . 0 0 1}{ }^{\mathbf{a}}\end{array}$ & $\begin{array}{l}40 \\
70 \\
0\end{array}$ & $\begin{array}{l}100 \\
100 \\
40\end{array}$ & $\begin{array}{l}71.58 \pm 16.1 \\
84.21 \pm 8.38 \\
12.63 \pm 13.27 \\
\mathbf{p}=\mathbf{0 . 0 0 2}^{\mathbf{a}}\end{array}$ & $\begin{array}{l}0.088^{b} \\
\mathbf{0 . 0 1 1}^{\text {b* }} \\
0.721^{b}\end{array}$ \\
\hline $\begin{array}{l}\text { Perilaku } \\
\text { - Sebelum } \\
\text { - Setelah } \\
\text { - } \Delta \text { skor perilaku } \\
P\end{array}$ & $\begin{array}{l}50 \\
50 \\
-10\end{array}$ & $\begin{array}{l}100 \\
100 \\
30\end{array}$ & $\begin{array}{l}70.43 \pm 3.23 \\
75 \quad \pm 2.80 \\
4.78 \pm 10.39 \\
\\
\mathbf{p}=\mathbf{0 . 0 3 8}^{\mathbf{a}}\end{array}$ & $\begin{array}{l}50 \\
60 \\
-20\end{array}$ & $\begin{array}{l}80 \\
90 \\
20\end{array}$ & $\begin{array}{l}68.42 \pm 9.58 \\
74.74 \pm 9.05 \\
6.32 \pm 10.17 \\
\\
\mathbf{p}=\mathbf{0 . 0 2 8}^{\mathbf{a}}\end{array}$ & $\begin{array}{l}0.696^{b} \\
0.948^{b} \\
0.413^{b}\end{array}$ \\
\hline
\end{tabular}

Keterangan : a: paired test wilcoxon b:independent test mann whitney 
Pada kelompok perlakuan dan kontrol, rerata pengetahuan sebelum pemberian penyuluhan MP-ASI tidak terdapat perbedaan bermakna $(p=0.088)$, sebelum perlakuan, keduanya belum mencapai skor 80, namun setelah pemberian pelatihan dan modul,hasil analisis statistik menunjukkan bahwa pada kelompok perlakuan, rerata pengetahuan meningkat secara signifikan $(\mathrm{p}=0.001)$, begitu juga pada kelompok kontrol yang diberikan penyuluhan MP-ASI namun tidak diberikan pelatihan pembuatan MP-ASI, pengetahuan meningkat secara signifikan namun nilai reratanya lebih rendah dari kelompok perlakuan $(\mathrm{p}=0.002)$.

Hasil analisis statistik menunjukkan bahwa antara kelompok perlakuan dan kelompok kontrol terdapat perbedaan rerata skor pengetahuan yang signifikan dengan hasil lebih baik pada kelompok perlakuan $(\mathrm{p}=0.011)$. Hal ini membuktikan bahwa pemberian penyuluhan dengan Modul MPASI ditambah dengan praktik pembuatan MPASI lebih efektif untuk meningkatkan pengetahuan ibu mengenai pemberian MP-ASI yang seimbang pada anak dibandingkan dengan yang hanya diberi penyuluhan menggunakan Modul MP-ASI.

Hasil rerata skor Perilaku pemberian MP-ASI pada kelompok perlakuan dan kelompok kontrol menunjukkan perubahan signifikan $(\mathrm{p}=0.038 ; \mathrm{p}=0.028)$, namun peningkatan skor perilaku pada dua kelompok tersebut belum mencapai skor 80 atau menjawab minimal $80 \%$ pernyataan perilaku secara benar. Hasil uji statistik menunjukkan tidak ada perbedaan rerata skor perilaku pemberian MP-ASI sebelum dan sesudah penyuluhan MP-ASI antara kelompok perlakuan dan kelompok kontrol ( $p>0.05)$. Hal ini dikarenakan pengambilan data dilakukan tepat setelah pemberian intervensi sehingga dampaknya terhadap perbedaan skor perilaku pada kedua kelompok tersebut tidak ada. Sedangkan hasil uji statistik untuk perbedaan rerata perubahan atau selisih skor pengetahuan dan perilaku pada kelompok perlakuan dan kelompok kontrol menunjukkan tidak ada perbedaan perubahan skor pengetahuan dan perilaku $(\mathrm{p}=0.721 ; \mathrm{p}=0.413)$.

Hasil penelitian ini sejalan dengan penelitian oleh Manikyamba et al (2015) tentang pengaruh pemberian edukasi gizi pada pengetahuan ibu terhadap pemberian MP-ASI. Dalam penelitian tersebut,uji statistik menunjukkan perubahan signifikan pada pengetahuan ibu tentang MP-ASI setelah diberikan edukasi gizi. Perbaikan tersebut meliputi pengetahuan MP-ASI terkait frekuensi dan kuantitas pemberian MP-ASI.

Sejalan dengan penelitian Manikyamba et al, penelitian oleh Hestuningtyas (2013) tentang pengaruh konseling gizi terhadap pengetahuan sikap dan perilaku ibu dalam pemberian makan anak dan asupan zat gizi pada anak stunting di Semarang menunjukkan perbedaan yang bermakna pada pengetahuan MP-ASI ibu, pada kelompok dengan perlakuan dan kontrol, akan tetapi untuk kelompok yang diberikan konseling gizi terdapat perbedaan bermakna dalam hal pengetahuan, sikap, dan praktik pemberian MP-ASI sementara pada kelompok kontrol hanya terdapat perbedaan pada pengetahuan saja. Pada penelitian di Karachi, Pakistan oleh Saleem et al (2014) mengenai pengaruh 
edukasi gizi pada ibu tentang MP-ASIterhadap status gizi anak, yang dilakukan selama 30 minggu, memberikan dampak positif pada penambahan berat badan, tinggi badan dan lingkar lengan atas, serta menurunkan prevalensi stunting dan gizi kurang sebesar $10 \%$ pada kelompok yang diberikan edukasi tersebut. Jika pengetahuan dan perilaku ibu tentang pemberian MP-ASI baik, maka akan berdampak positif terhadap status gizi anak sehingga dapat mencegah terjadinya malnutrisi dengan pemberian MP-ASI yang seimbang, mencukupi kebutuhan gizi anak.

\section{Daftar Pustaka}

1. [ASDI, IDAI, PERSAGI]. Asosiasi Dietisien Indonesia, Ikatan Ahli Gizi Indonesia, Persatuan Ahli Gizi Indonesia. 2015. Penuntun Diet Anak. Jakarta : FKUI

2. Chandradewi, dkk. 2012. Pengaruh Penyuluhan Gizi terhadapa Pola Pemberian MP-ASI, Berat badan, Status gizi Anak usia 6 - 24 bulan di Kelurahan Selagalas Kota Mataram. Jurnal Kesehatan Prima Vol. 6 No. 1 Februari 2012 hal. 849 - 859

3. [Depkes RI], Departemen Kesehatan RI. Pedoman Pemberian Makanan Pendamping ASI MP-ASI), Dirjen Bina Kesehatan Masyarakat, Departemen Kesehatan, Jakarta. 2004

4. [Depkes RI]. Departemen Kesehatan RI. 2000. Makanan Pendamping Air Susu Ibu. Jakarta
5. Dewi, dkk. 2010. Hubungan Pola Pemberian Makanan Pendamping Asi (MP-ASI) Dengan Status Gizi Pada Balita Usia 6-12 Bulan Di Desa Kaliori Kecamatan Kalibagor Kabupaten Banyuma. YLPP Purwokerto : Jurnal

6. Ehok, dkk. 2015. Hubungan Tingkat Pengetahuan Ibu Tentang Makanan Pendamping Air Susu Ibu Terhadap Status Gizi Bayi Usia 6-12 Bulan Di Wilayah Kerja Puskesmas Pakis. Universitas Katolik Widya Mandala Surabaya : Skripsi

7. Ezzat, Sally. 2007. Factors Affecting Complementary Feeding Pattern in Alexandria. Bulletin of High Institute of Public Health, Vo. 37 No. 4

8. Hestuningtyas, T.R.2013.Pengaruh Konseling Gizi terhadap pengetahuan, sikap,praktik ibu dalam pemberian makan anak dan asupan zat gizi anak stunting usia 1 -2 tahun di kecamatan Semarang Timur. Semarang: Fakultas Kedokteran Universitas Diponegoro. Artikel Penelitian.

9. Jumyati, 2016. Nutrition Education Improves Mother's Knowledge and Attitude in the provision of Complementary Foods. International Conference on Health and Well Being 2016. Articles.

10. Kusumasari, dkk. 2013. Hubungan Pengetahuan Ibu Tentang Makanan Pendamping ASI Dengan Status Gizi 
Bayi Pada Anak Di Wilayah Kerja Puskesmas Juwiring Klaten. Klaten : Jurnal

11. Kolifah, dkk. 2014. Pengaruh Perilaku Ibu Dalam Memberikan Makanan Pendamping ASI Terhadap Status Gizi Bayi Usia 7-12 Bulan. Jombang : Jurnal

12. Manikyamba et al. 2015.Impact of Nutritional Education on the Knowledge of Mothers regarding Infant and Young Child Feeding Practices. Scholars Journal of Applied Medical Sciences (SJAMS) 2015: 3 (34):1074-1078. ISSN 2347-954X.

13. Notoatmodjo. S. 2012. Metodologi Penelitian Kesehatan. Rineka Cipta. Jakarta

14. Prihati, dkk. 2009. Hubungan Pengentahuan Ibu Tentang Makanan Pendamping ASI (MP-ASI) Dengan Status Gizi Balita Usia 6-23 Bulan Di Desa Parangjoro Kabupaten Sukoharjo. Poltekes Kemenkes Surakarta : Jurnal

15. Priyoto. 2015. Perubahan Dalam Perilaku Kesehatan (Teori Lawrence Green). Yogyakarta : Graha Ilmu

16. Rakhmawati. 2012. Hubungan Pengetahuan Dan Sikap Ibu Dengan Perilaku Ibu Dalam Pemberian Makanan Anak Usia 12-24 Bulan. Universitas Diponegoro : Artikel

17. Retno, A.S.,et al.2013. Pengaruh Pemberian Makanan Pada Bayi dan Anak terhadap Pengetahuan,
Keterampilan, dan Motivasi Bidan Desa. Jurnal DIKESA Januari 2013 hal. 1 -20.

18. [RISKESDAS]. Riset Kesehatan Dasar. 2013. Kesehatan Anak dan Status Gizi.Badan Penelitian Dan Pengembangan Kesehatan Kementrian Kesehatan RI.

19. Patil et al. 2016. Study of Complementary Feeding Practices in Mothers of Infantas aged 6-12 months. International Journal of Pediatric Research. Vol.3. ISSN 2349-5499.

20. Rochimawati, Siti Nur et al.2013. Studi Pemberian MP-ASI Dini dan Status Gizi Bayi Umur 0 -6 Bulan di Kelurahan Botang Kecamatan Makale Kabupaten Tana Toraja. Media Gizi dan Pangan Vol.XV Edisi I 2013.

21. Riwidikdo, H. 2012. Statistik Kesehatan. Yogyakarta. Nuha Medika

22. Sakti. 2013. Hubungan Pola Pemberian Mp-Asi Dengan Status Gizi Anak Usia 6-23 Bulan Di Wilayah Pesisir Kecamatan Tallo Kota Makassar Tahun 2013. Makassar. Jurnal

23. Saleem et al. 2014. Impact of Maternal Education about Complementary Feeding on Their Infants. Nutritional Outcomes in low - middle Income Households: a community based randomized interventional study in Karachi, Pakistan. Helath Population Nutritition, 2014, ISSN: 16060997. 
24. Sari. 2005. Hubungan Pengetahuan Dan Sikap Ibu Terhadap Perilaku Pemberian Makanan Pendamping ASI (MP-ASI) Pada Bayi 6-12 Bulan Di Puskesmas Cimahi Selatan Kota Cimahi. FKM UI. Skripsi

25. Saryono. 2011. Metodologi Penelitian. Mitra Cendikia Press. Jogjakarta

26. Setianingsih. 2013. Hubungan Perilaku Ibu Dalam Pemberian MP-ASI Dengan Status Gizi Anak Usia 6-24 Bulan Di Posyandu Kelurahan Wirobrajan Yogyakarta. Yogyakarta : Jurnal

27. Septiana, dkk. 2009. Hubungan Antara Pola Pemberian Makanan Pendamping ASI (MP-ASI) Dan Status Gizi Balita Usia 0-24 Bulan Di Wilayah Kerja Puskesmas Gedong Tengen Yogyakarta. Yogyakarta : Jurnal

28. Supariasa, I Dewa Nyoman, Bachyar Bakri, dan Ibnu Fajar. 2002. Penilaian Status Gizi. Jakarta : EGC
29. Syofiah. 2013. Faktor-Faktor Yang Mempengaruhi Kejadian Gizi Kurang Pada Balita Di Wilayah Kerja Puskesmas Air Dingin Kota Padang. Padang Jurnal

30. Taufiqurrahman, dkk 2012. Hubungan Antara Pendidikan Dan Pengetahuan Ibu Balita Dengan Pola Pemberian MPASI Pada Anak Usia 6-24 Bulan Di Kelurahan Karang Baru Selaparang, Mataram Nusa Tenggara Barat. Nusa Tenggara Barat : Jurnal

31. Wargiana. 2013. Hubungan Pemberian MP-ASI Dini Dengan Status Gizi Bayi Umur 0-6 Bulan Di Wilayah Kerja Puskesmas Rowotengah Kabupaten Jember. Universitas Jember : Skripsi 